\title{
PENGARUH KETERAMPILAN PROSES SAINS, PENALARAN, DAN PEMECAHAN MASALAH TERHADAP HASIL BELAJAR FISIKA
}

\author{
NAPIS MARKAWI \\ nafis_me@yahoo.co.id \\ 087886555205 \\ Program Studi Pendidikan Matematika, Fakultas Teknik, Matematika dan IPA \\ Universitas Indraprasta PGRI (UNINDRA)
}

\begin{abstract}
This causal research is aimed at obtaining information related to the effect of science process skills, reasoning, and problem solving on physics learning outcomes. The research had been held in SMAN 28 South of Jakarta. In this research, 100 samples were selected randomly, and data were collected through survey, test, and documentation. The data has been analyzed by path analysis after all variables put into the correlation matrix and use of structural equations to calculate path coefficient. The finding of the research shows that student's physics learning outcomes is affected positively direct by science process skills, reasoning, and problem solving. Based on those findings, it could be concluded that increasing of student's physics learning outcomes might be affected by science process skills, reasoning, and problem solving. Therefore, the results of this research will be implicate on the learning method, and arrangement of physics learning outcomes test, which measure science process skills, reasoning and problem solving ability. Teacher use appropriate learning method with notice student cognitive development, for better achievement physics learning outcomes. However, other variables are necessary to be taken in to account by next physics learning outcomes research.
\end{abstract}

Keywords: science process skills, reasoning, problem solving, physics learning outcomes

\section{PENDAHULUAN}

Mutu pendidikan Indonesia yang rendah telah banyak disadari oleh berbagai pihak, terutama oleh para ahli dan pemerhati pendidikan. Dalam bidang MIPA, mutu pendidikan di Indonesia juga tergolong rendah, seperti diungkapkan oleh the Trends in International Mathematics and Science Study (TIMSS), bahwa di antara 49 negara peserta pada tahun 2007, Indonesia berada pada urutan ke-35 untuk bidang sains fisika, Efendi (2010). Hasil temuan menyimpulkan bahwa kecenderungan capaian fisika siswa Indonesia selalu menurun pada tiap aspek kognitif. Hal ini mengindikasikan kemampuan fisika siswa harus ditingkatkan pada semua aspek, khususnya aspek reasoning.

Rendahnya mutu pendidikan dapat pula dilihat dalam laporan studi Programme for International Student Assessment (PISA). Pada tahun 2003 gambaran kualitas pembelajaran di Indonesia untuk Literasi Sains dan Matematika, peserta didik usia 15 tahun berada pada ranking ke 38 dari 40 negara peserta, menunjukkan profil kemampuan diantaranya sains, dan problem solving,Tjala (2009). The World Bank menemukan perbandingan akses dan kualitas tentang prestasi pendidikan di beberapa negara. Output pendidikan di Indonesia hanya mencapai tingkat-tingkat berpikir rendah, yaitu pengetahuan, pemahaman, dan aplikasi, sedangkan untuk tingkat-tingkat berpikir yang tinggi, seperti analisis, evaluasi, dan kreativitas masih sangat rendah. Siswa-siswa Indonesia hanya dapat menjawab soal-soal hapalan tetapi tidak dapat menjawab soal-soal yang memerlukan penalaran atau keterampilan proses. 
Berdasarkan data tersebut, evaluasi dari berbagai aspek pembelajaran perlu dilakukan untuk perbaikan misalnya dari aspek input, proses, dan output. Dari aspek input, saat ini sudah berlaku Kurikulum Tingkat Satuan Pendidikan (KTSP) yang merupakan penyempurnaan dari kurikulum sebelumnya. Pembelajaran fisika diarahkan agar dapat mengembangkan kemampuan berpikir dan penyelesaian masalah baik secara kualitatif maupun secara kuantitatif dengan menggunakan matematika serta dapat mengembangkan pengetahuan, keterampilan, dan sikap percaya diri. Dari aspek proses, bahwa pembelajaran fisika mestinya menggunakan berbagai macam pendekatan, strategi, metode, atupun model pembelajaran. Pendekatan pembelajaran yang bisa digunakan misalnya keterampilan proses sains (science process skills). Jika standar proses dilaksanakan dengan baik, maka output pendidikan sesuai dengan apa yang dituangkan dalam standar kompetensi lulusan yang mencakup pengetahuan, niliai, sikap, dan keterampilan.

Pembelajaran fisika terkadang kurang mengeksplorasi kemampuan berpikir atau bernalar sehingga kemampuan menjawab soal-soal fisika masih rendah. Kemampuan berpikir digunkan untuk menguhubungkan berbagai aspek yang bisa di interpretasikan dalam soal fisika. Oleh karena itu, untuk memahami dan menguasai konsep, prinsip, dan teori, serta hukum fisika memerlukan kemampuan penalaran. Soal fisika menuntut kemampuan siswa dalam menggunakan logika berpikirnya dalam menjawab, atau menyelesaikan soal-soal fisika. Oleh karena itu pemahaman atau penguasaan terhadap konsep, prinsip, teori, maupun hukum fisika memungkinkan siswa dapat menyelesaikan soal fisika. Permasalahan yang dihadapi siswa dalam memecahkan soal-soal tes fisika, banyak diantara siswa yang tidak memiliki kemampuan menyelesaikan soal-soal secara sistematis, sulit mencerna pokok pertanyaan, tidak mudah menentukan besaran-besaran fisika dan simbol-simbol yang terdapat dalam pertanyaan. Siswa juga terkadang masih sulit menentukan konsep, prinsip, teori, hukum dan rumus yang dipakai untuk memecahkan, menjawab atau menyelesaikan soal.

Definisi konseptual untuk setiap variabel dijelaskan sebagai berikut: hasil belajar fisika, yang terdiri dari konsep belajar, hasil belajar, dan hasil belajar fisika. Menurut Sardiman (2007: 22-23), belajar dalam arti luas adalah kegiatan psikofisik menuju perkembangan pribadi seutuhnya. Sedangkan dalam arti sempit, belajar adalah usaha penguasaan ilmu pengetahuan dan teknologi. Perkembangan fisik maupun mental sebagai akibat dari proses belajar. Hilgard, seperti dikutip Nasution (2010: 35) mengungkapkan belajar adalah sebuah proses yang menghasilkan atau mengubah suatu kegiatan melalui latihan yang dibedakan dari faktor-faktor yang tidak termasuk latihan, contohnya eksperimen, praktikum atau percobaan, dan penelitian di laboratorium.

Sudjana (1989: 22) mendefinisikan bahwa hasil belajar merupakan kemampuankemampuan (kompetensi) yang dimiliki peserta didik setelah menerima pengalaman belajar. Gronlund (1990: 29-31) menjelaskan hasil belajar (learning outcomes), meliputi beberapa aspek yaitu: (1) pengetahuan, (2) pemahaman, (3) aplikasi, (4) kemampuan berpikir, (5) kemampuan umum, (6) sikap, (7) minat, (8) apresiasi, dan (9) penyesuaian. Lebih spesifik lagi menurut Gagne (1983: 27-28), hasil belajar meliputi lima aspek yaitu; (1) informasi verbal, (2) kemahiran intelektual, (3) pengaturan kegiatan kognitif, (4) keterampilan motorik, dan (5) sikap. Sementara menurut Bloom (1978: 7) hasil belajar berupa perubahan tingkah laku yang membentuk kemampuan manusia, dapat diklasifikasikan ke dalam tiga ranah, yaitu ranah kognitif, afektif, dan psikomotorik.

Hasil belajar fisika dapat dilihat pada Peraturan Menteri Pendidikan Nasional Nomor 23 tahun 2006 tentang Standar Kompetensi Lulusan mata pelajaran fisika SMA dalam Pustaka Yustisia (2007: 106), yaitu: dapat melakukan percobaan, merumuskan masalah, mengajukan dan menguji hipotesis, menentukan variabel, merancang dan 
merakit instrumen, mengumpulkan, mengolah dan menafsirkan data, menarik kesimpulan, serta mengkomunikasikan hasil percobaan secara lisan dan tertulis. Berdasarkan uraian di atas, maka dapat disimpulkan bahwa hasil belajar fisika merupakan standar kompetensi dan kompetensi dasar yang meliputi pengetahuan, konsep, teori, prinsip, dan hukum fisika yang dimiliki oleh siswa setelah mengikuti proses pembelajaran. Hasil belajar fisika dapat diketahui setelah melakukan pengukuran, penilaian, dan evaluasi.

Hasil belajar tersebut dapat di wujudkan dengan pembelajaran fisika yang memiliki karakteristik tersendiri. Menurut Whelan (1987: 12), karakteristik fisika yaitu mengukur hal-hal yang bersifat fisik, tidak bersifat abstrak, bahkan dapat mengukur secara kuantitatif. Giambattista (2010: 2) mengungkapkan fisika adalah cabang sains yang menggambarkan bahan, energi, ruang dan waktu dan semua tingkat yang fundamental, termasuk logika berpikir dan analisis, pemecahan masalah, asumsi sederhana, menyusun metode matematika, menggunakan prediksi yang valid, dan membuat definisi yang tepat. Menurut Young et al (2002: 1) pemahaman terhadap fenomena, gejala alam, yang diinterpretasikan dan dikonstruk menjadi pengetahuan, konsep, prinsip, teori, hukum, yang memerlukan kemampuan berpikir yang tinggi. Pembelajaran fisika dapat melatih kemampuan kognitif, psikomotorik, dan melatih sikap (afektif).

Pembelajaran fisika saat ini hendaknya melatih kemampuan memecahkan suatu masalah. Pemecahan masalah berkaitan dengan proses berpikir. Hamalik (2010: 151) masalah pada hakekatnya adalah suatu pertanyaan yang mengundang jawaban, suatu proses mental dan intelektual dalam menemukan suatu masalah dan memecahkannya berdasarkan data dan informasi yang akurat, sehingga dapat diambil kesimpulan yang tepat dan cermat. Pemecahan masalah merupakan proses memikirkan dan mencari jalan keluar bagi masalah tersebut. Menurut Nasution (2010: 66), bahwa pemecahan masalah menggunakan metode ilmiah dengan berpikir lebih sistematis, logis, lebih teratur, dan teliti. Pemecahkan masalah menurut Rosser dan Nigholson (1984: 450) merupakan suatu proses yang dilakukan seorang untuk menemukan solusi dengan menggunakan kombinasi pengetahuan ataupun peraturan-peraturan yang telah dipahami dan dikuasai untuk digunakan dalam memecahkan masalah dalam situasi yang baru. Pemecahan masalah juga merupakan aktivitas kognitif, menggunakan kombinasi pengetahuan, mengarah kepada inferensi-inferensi sampai pada kesimpulan. Menurut Nitko (2001: 212) pemecahan masalah dilakukan melalui strategi heuristik, meliputi langkah melihat gambaran masalah secara umum, sketsa, diagram, grafik, persamaan dan besaran yang terkait, fleksibel, menyebar ke berbagai fokus (divergen) dengan menggunakan analogianalogi atau penalaran. Santrock (2010: 372) strategi yang lain adalah algoritma, yaitu strategi yang menjamin solusi atas suatu permasalahan. Menggunakan rumus, persamaan, instruksi, dan mencoba kemungkinan alternatif pemecahan masalah.

Pemecahan masalah dalam soal, menurut Hopkins dan Antes (1990: 247) dapat dilakukan dengan baik jika mengetahui inti permasalahnnya. Pendekatan pemecahan masalah dalam fisika menurut Reif (1995: 17-32), melalui langkah: (1) analisis soal, untuk memahami soal secara keseluruhan melalui identifikasi dan interpretasi informasi penting, mendeskripsikan situasi soal menggunakan kalimat, diagram, skema ataupun istilah yang lebih teknis, (2) menyusun konstruksi pemecahan menggunakan hasil analisis soal, dan menentukan rumus. Jika soal cukup kompleks, mengurai (decompose) soal menjadi bagian-bagian soal yang lebih sederhana yang disebut sub-sub soal, dan (3) pemeriksaan ulang pemecahan, langkah ini penting untuk memastikan apakah proses pemecahan dan jawaban soal yang diperoleh sudah benar. Dengan demikian pemecahan masalah yang dimaksud dalam penelitian ini adalah kemampuan dalam menggunakan proses berpikir dengan menekankan pentingnya prosedur, langkah-langkah sistematis, 
tahapan, dan strategi yang ditempuh siswa dalam menyelesaikan masalah dalam soal hingga menemukan jawaban.

Pengetahuan dibentuk berdasarkan pemikiran atau argumen-argumen yang rasional, dan logis. Kemudian proses berpikir yang demikian adalah berpikir atau bernalar. Logika adalah sesuatu yang diutarakan, suatu peretimbangan akal pikiran, kata, percakapan, atau ungkapan lewat bahasa (Rapar, 1996: 9). Menurut Suariasumantri (1998: 43) penalaran adalah suatu kegiatan berpikir yang mempunyai ciri-ciri tertentu yaitu logis dan analitik. Anderson (1985: 3) mengatakan penalaran menunjukkan suatu proses seseorang menilai dan mengemukakan argumentasi-argumentasi yang logis. Penalaran merupakan argumentasi-argumentasi logis dan terarah. Small (1996: 256), penalaran adalah suatu penjelasan yang menunjukkan kaitan atau hubungan antara dua hal atau lebih yang atas dasar alasan-alasan tertentu dan dengan langkah-langkah tertentu sampai pada kesimpulan. Menurut Santrock (2008: 358), bahwa penalaran adalah berpikir logis yang menggunakan induktif dan deduktif untuk menarik kesimpulan. Menurut Barbey dan Barsalou (2008: 35) dalam tulisannya yang berjudul Reasoning and Problem Solving, mengungkapkan bahwa penalaran merupakan tanda bahwa manusia berfikir, mendukungnya proses penemuan yang dapat menuntun dari apa yang diketahui atau yang dapat disimpulkan terhadap apa yang tersirat dalam sebuah pemikiran.

Penalaran merupakan kemampuan kognitif seseorang. Menurut teori kognitif Piaget, dalam Yusuf (2001: 6), perkembangan kognitif meiputi empat tahap atau periode. Pertama, sensorimotor (0-2 tahun). Kedua, praoperasional (2-6 tahun). Ketiga, Operasi konkret (6-11 tahun). Keempat, operasi formal (11 tahun- dewasa), operasi mental tingkat tinggi, berhubungan dengan berpikir abstrak dan berhipotesis, memecahkan masalah melalui pengujian semua aternatif. Monk $d k k$ (2004: 223) perkembangan kognitif di atas menunjukkan bahwa tahap operasi konkrit dan formal memiliki kemampuan pemecahan masalah. Anak yang berpikir operasi konkrit langsung mencoba beberapa penyelesaian secara konkrit. Sedangkan anak yang berpikir operasi formal, memikirkan secara teoretis, menganalisis masalah dengan berbagai hipotesis, kemudian menyusun strategi pemecahan masalah. Menurut Hergenhahn dan Olson (2008: 318-320), pada tahap operasi konkrit, anak dapat mengembangkan kemampuan mempertahankan (konservasi), kemampuan mengelompokkan secara memadai, pengurutan, dan konsep angka. Sedangkan tahap operasi formal, anak dapat menangani situasi hipotesis, berpikir tidak hanya langsung dan riil, dan pemikiran anak semakin logis.

Sains sebagai suatu proses merupakan cara untuk memperoleh pengetahuan. Ilmuan menggunakan berbagai keterampilan metode ilmiah, yang disebut keterampilan proses sains. Keterampilan proses sains juga merupakan salah satu pendekatan dalam mempelajari sains. Wolfinger (1994: 241) menyatakan keterampilan proses merupakan teknik yang digunakan oleh para ilmuan untuk memperoleh informasi. Whyne (1985: 5) menyatakan keterampilan proses merupakan prosedur yang digunakan untuk mencari dan mengolah informasi. Beyer (1991: 9) mengungkapkan bahwa keterampilan proses dapat digunakan sebagai alat atau piranti (tools) untuk memahami materi. Cain dan Evans (1990: 54) menyatakan bahwa keberhasilan belajar ditentukan oleh pengembangan keterampilan proses sains.

Menurut Gega (1997: 43), keterampilan proses sains disebut keterampilan berpikir (thinking skills), yang sering digunakan oleh para ilmuan. Keterampilan berpikir tersebut meliputi: pengamatan, komunikasi, klasifikasi, inferensi, pengukuran dan eksperimen. Keterampilan proses sains tersebut diharapkan akan membentuk pemahaman terhadap fakta dan konsep ilmu pengetahuan termasuk proses dan produk, serta niai, dan sikap ilmiah. Keterampilan proses sains menurut Syarif, dkk (2010: 119-121), yang dapat digunakan untuk memperoleh dan memproses pengetahuan adalah: mengobservasi 
merupakan keterampilan mengumpulkan data melalui hasil-hasil pengamatan pancaindera. Kegiatan pengamatan meliputi: melihat, mendengar, meraba, membaui, mencicipi, mengecap, menyimak, membaca, menghitung, mengukur, mengklasifikasi, mencari hubungan ruang dan waktu.

Keterampilan proses sains menurut Abruscato (1994: 42), terbagi menjadi dua, yaitu; keterampilan proses dasar (basic skills), dan keterampilan proses terintegrasi (integrated skills). Sedangkan dan Lind (1995: 44-45), keterampilan proses dikelompokkan menjadi tiga, yaitu; keterampilan proses dasar (basic), keterampilan proses menengah (intermediate), dan keterampilan lanjutan (advanced). Keterampilan proses dasar (basic process) menurut Abruscato (1994: 42) meliputi: mengamati, menggunakan angka, mengklasifikasi, mengukur, mengkomunikasikan, memprediksi, dan menyimpulkan. Charlesworth dan Lind (1995: 44-45), keterampilan proses menengah (intermediate process skills) yang meliputi: menyimpulkan, dan memprediksi, keterampilan lanjutan (advanced process skills) meliputi: merumuskan hipotesis, menentukan dan mengontrol variabel. Berdasarkan uraian di atas, keterampilan proses sains merupakan keterampilan yang dimiliki oleh ilmuan, kemampuan yang komprehensif, sistematis, analisis berdasarkan logika berpikir, serta metodologis, melibatkan aktivitas fisik maupun mental, dalam menggali, memperoleh, memahami, serta menguasai ilmu pengetahuan.

\section{METODE}

Penelitian ini menggunakan pendekatan kuantitatif, metode survei, dan teknik analisis jalur (path analysis). Berdasarkan kajian teoretik, maka model konseptual hubungan antar variabel dapat dilihat seperti pada desain penelitian berikut:



Gambar 1. Diagram Analisis Jalur

Dalam penelitian ini yang menjadi populasi target adalah seluruh siswa SMA Negeri 28 Jakarta Selatan. Populasi terjangkau adalah siswa kelas XI IPA berjumlah 144 siswa, dan sebanyak 100 siswa dipilih sebagai sampel penelitian, yang diambil melalui teknik acak sederhana (simple random sampling). Analisis yang digunakan meliputi: analisis deskriptif, analisis terhadap uji persyaratan, dan analisis inferensial. Pengujian persyaratan yang dilakukan adalah: (1) Uji normalitas data menggunakan persamaan regresi untuk uji normalitas galat taksiran linieritas regresi dengan teknik Lilliefors, (2) Uji multikolinieritas, (3) Uji linieritas regresi, menggunakan uji persamaan regresi dengan Analisis varians (Anava). 
Analisis inferensial digunakan untuk menganalisis data sampel, dan hasilnya akan digeneralisasikan untuk populasi dimana sampel di ambil. Analisis data untuk menguji hipotesis menggunakan analisis jalur (path analysis), melalui beberapa tahap: (1) menyusun matrik koefisien korelasi, koefisien korelasi dihitung dengan rumus product moment. (2) menurut Sugiyono (2009: 314), menghitung koefisien jalur berdasarkan model teoretik penelitian, hubungan kausal, dan analisis korelasi digunakan untuk menghitung koefisien jalur dengan persamaan struktural, serta menghitung koefisien determinasi $\left(R^{2}{ }_{y x}\right)$ dan residu $(\varepsilon)$, untuk mengetahui besar pengaruh variabel lain yang tidak dikaji dalam disain penelitian. (3) Pengujian model, menurut Sudjana (2001: 303), dapat menggunakan pendekatan pragmatis dengan menghitung semua koefisien jalur dalam model kemudian menyaring berdasarkan uji statistik dan keberartian, menggunakan pegangan bahwa jalur kurang dari 0,05 dapat dianggap tidak berarti. Pengujian koefisien jalur juga dilakukan dengan $u j i-t$, koefisien jalur dikatakan signifikan jika $t_{\text {hitung }}>t_{\text {tabel }}$, pada tingkat kepercayaan $5 \%(\alpha=0,05)$. (4) Menghitung besar pengaruh langsung (direct effect) dapat dihitung dengan menggunakan koefisien jalur yang diperoleh, dengan cara mengalikan koefisien jalur.

\section{HASIL PENELITIAN DAN PEMBAHASAN}

\section{Hasil Analisis Deskriptif}

Penelitian ini meliputi 4 (empat) variabel, yaitu: variabel Hasil Belajar Fisika $\left(\mathrm{X}_{4}\right)$ sebagai variabel endogen atau variabel terikat (dependent), sedangkan variabel Keterampilan Proses Sains $\left(\mathrm{X}_{1}\right)$, Penalaran $\left(\mathrm{X}_{2}\right)$, dan variabel Pemecahan Masalah $\left(\mathrm{X}_{3}\right)$ sebagai variabel eksogen atau variabel bebas (independent). Rangkuman deskripsi statistik disajikan pada tabel berikut:

Tabel 1. Statistik Deskriptif

\begin{tabular}{|l|c|c|c|c|}
\hline \multirow{2}{*}{ Deskripsi } & \multicolumn{4}{c|}{ Variabel } \\
\cline { 2 - 5 } & $\mathbf{X}_{\mathbf{1}}$ & $\mathbf{X}_{\mathbf{2}}$ & $\mathbf{X}_{\mathbf{3}}$ & $\mathbf{X}_{\mathbf{4}}$ \\
\hline $\begin{array}{l}\text { Jumlah sampel } \\
\text { (n) }\end{array}$ & 100 & 100 & 100 & 100 \\
\hline Rerata (Mean) & 24,29 & 34,43 & 53,82 & 84,05 \\
\hline Median & 25 & 35 & 54 & 84 \\
\hline Modus & 25 & 35 & 56 & 87 \\
\hline Standar Deviasi & 3,41 & 3,49 & 3,99 & 4,04 \\
\hline Variansi & 11,64 & 12,19 & 15,99 & 16,33 \\
\hline Skor Minimum & 15 & 25 & 45 & 77 \\
\hline Skor Maksimum & 30 & 40 & 60 & 92 \\
\hline Jumlah & 2429 & 3443 & 5382 & 8405 \\
\hline
\end{tabular}

Tabel tersebut memperlihatkan deskripsi data yang diperoleh dari 100 responden yang diolah menggunakan program SPSS 17. Skor Keterampilan Proses Sains $\left(\mathrm{X}_{1}\right)$ memiliki nilai rerata 24,29, dan Standar deviasi 3,41. Skor Penalaran $\left(X_{2}\right)$ memiliki nilai rerata 34,43, dan Standar deviasi 3,49. Skor Pemecahan Masalah $\left(\mathrm{X}_{3}\right)$ memiliki nilai rerata 53,82, dan Standar deviasi 3,99. Sedangkan skor Hasil Belajar Fisika $\left(\mathrm{X}_{4}\right)$ memiliki nilai rerata 84,05, dan Standar deviasi 4,04. Deskripsi statistik tersebut menunjukkan rerata skor untuk variabel $\mathrm{X}_{4}$ cenderung meningkat dari rerata skor variabel $\mathrm{X}_{1}, \mathrm{X}_{2}$, dan $\mathrm{X}_{3}$. 


\section{Hasil Pengujian Persyaratan Analisis}

Prosedur sebelum melakukan pengujian hipotesis pada analisis jalur (path analysis) adalah melakukan pengujian persyaratan analisis. Pengujian persyaratan analisis melalui 3 (tiga) tahap, yaitu: uji normalitas galat, multikolinieritas, dan linieritas regresi. Uji persyaratan normalitas data dilakukan dengan uji normalitas galat taksiran dengan teknik Lilliefors. Perhitungan menggunakan Microsoft Office Excel 2007, dengan menentukan nilai mutlak maksimum selisih proporsi skor baku $|S(n)-F(Z)|$, nilai mutlak maksimum disebut sebagai $L_{O}$. Jika $L_{O}<L_{\text {tabel }}$, maka data berdistribusi normal. Rangkuman hasil uji normalitas galat taksiran regresi linier adalah sebagai berikut:

Tabel 2. Hasil Pengujian Normalitas

\begin{tabular}{|c|c|c|c|c|}
\hline \multirow{2}{*}{ Variabel } & \multirow{2}{*}{$L_{\text {Observasi }}$} & \multicolumn{2}{|c|}{$L_{\text {tabel }}$} & \multirow{2}{*}{ Kesimpulan } \\
\cline { 3 - 4 } & & $\boldsymbol{\alpha}=\mathbf{0 , 0 5}$ & $\begin{array}{c}\boldsymbol{\alpha} \\
=\mathbf{0 , 0 1}\end{array}$ & \\
\hline $\mathrm{X}_{4}$ atas $\mathrm{X}_{1}$ & 0,053 & 0,0886 & 0,1031 & Normal \\
\hline $\mathrm{X}_{4}$ atas $\mathrm{X}_{2}$ & 0,070 & 0,0886 & 0,1031 & Normal \\
\hline $\mathrm{X}_{4}$ atas $\mathrm{X}_{3}$ & 0,047 & 0,0886 & 0,1031 & Normal \\
\hline $\mathrm{X}_{3}$ atas $\mathrm{X}_{1}$ & 0,044 & 0,0886 & 0,1031 & Normal \\
\hline $\mathrm{X}_{3}$ atas $\mathrm{X}_{2}$ & 0,072 & 0,0886 & 0,1031 & Normal \\
\hline
\end{tabular}

Pengujian multikolinieritas diolah dengan menggunakan program SPSS 17. Hasil pengujian multikolinieritas disajikan pada tabel berikut:

Tabel 3. Hasil Pengujian Multikolinieritas

\begin{tabular}{|c|c|c|c|}
\hline \multirow{2}{*}{\multicolumn{2}{|c|}{ Model }} & \multicolumn{2}{|c|}{ Collinearity Statistics } \\
\hline & & Tolerance & $V I F$ \\
\hline \multirow{3}{*}{1} & $\mathrm{X} 1$ & 0,628 & 1,592 \\
\hline & $\mathrm{X} 2$ & 0,655 & 1,528 \\
\hline & X3 & 0,673 & 1,486 \\
\hline
\end{tabular}

Berdasarkan tabel 3, menunjukkan bahwa hasil uji Colliniearity Statistics diperoleh nilai tolerance $>0,1$ dan nilai Ariance Inflation Factors $(V I F)<10$. Sehingga dapat disimpulkan bahwa tidak terdapat gejala multikolinieritas (irisan) di antara variabel eksogen (variabel independen). Hubungan antar variabel dinyatakan dengan persamaan regresi. Rangkuman hasil uji linieritas regresi adalah sebagai berikut:

Tabel 4. Hasil Anava Pengujian Linieritas Regresi

\begin{tabular}{|c|c|c|c|c|c|c|c|}
\hline \multirow{2}{*}{ No. } & \multirow{2}{*}{ Variabel } & \multicolumn{3}{|c|}{ Regresi } & \multicolumn{3}{|c|}{ Linieritas } \\
\hline & & $F_{\text {hitung }}$ & $F_{\text {tabel }(0,05)}$ & \multirow{6}{*}{$\begin{array}{l}F_{\text {hitung }} \\
>F_{\text {tabel }}\end{array}$} & $F_{\text {hitung }}$ & $F_{\text {tabel }(0,05)}$ & \multirow{6}{*}{$\begin{array}{c}F_{\text {hitung }}< \\
F_{\text {tabel }}\end{array}$} \\
\hline 1. & $\mathrm{X} 1-\mathrm{X} 4$ & 36,139 & 3,94 & & $-1,02$ & 1,87 & \\
\hline 2. & $\mathrm{X} 2-\mathrm{X} 4$ & 32,359 & 3,94 & & $-0,539$ & 1,81 & \\
\hline 3. & $\mathrm{X} 3-\mathrm{X} 4$ & 37,544 & 3,94 & & $-0,615$ & 1,81 & \\
\hline 4. & X1 - X3 & 35,462 & 3,94 & & $-1,107$ & 1,87 & \\
\hline 5. & X2 - X3 & 30,086 & 3,94 & & -0122 & 181 & \\
\hline
\end{tabular}

Tabel 4 menunjukkan hasil Anava uji koefisien regresi untuk setiap pasangan variabel signifikan. Sehingga dapat disimpulkan bahwa model hubungan antara variabel 
independen (eksogen) dengan variabel dependen (endogen) adalah linier. Model regresi dapat digunakan untuk memprediksi peningkatan skor variabel dependen (endogen).

Pengujian persyaratan analisis sudah dilakukan, sehingga dapat dilanjutkan langkah berikutnya yaitu pengujian hipotesis yang sebelumnya sudah melakukan perhitungan koefisien jalur. Langkah pertama menyajikan koefisien korelasi antar variabel yang disajikan dalam bentuk matriks koefisien korelasi seperti pada tabel berikut:

Tabel 5. Matriks Koefisien Korelasi

\begin{tabular}{|c|c|c|c|c|}
\hline Variabel & $\mathbf{X}_{\mathbf{1}}$ & $\mathbf{X}_{\mathbf{2}}$ & $\mathbf{X}_{\mathbf{3}}$ & $\mathbf{X}_{\mathbf{4}}$ \\
\hline $\mathbf{X}_{\mathbf{1}}$ & 1 & 0,535 & 0,515 & 0,519 \\
\hline $\mathbf{X}_{\mathbf{2}}$ & & 1 & 0,485 & 0,498 \\
\hline $\mathbf{X}_{\mathbf{3}}$ & & & 1 & 0,526 \\
\hline $\mathbf{X}_{\mathbf{4}}$ & & & & 1 \\
\hline
\end{tabular}

Rangkuman hasil perhitungan koefisien korelasi serta uji signifikansi koefisien korelasi disajikan dalam tabel berikut:

Tabel 6. Hasil Pengujian Signifikansi Koefisien Korelasi

\begin{tabular}{|c|c|c|c|c|c|}
\hline No & Variabel & $\begin{array}{c}\text { Koefisien } \\
\text { Korelasi }\end{array}$ & $t_{\text {hitung }}$ & $t_{\text {tabel }(\alpha=0,05)}$ & Kesimpulan \\
\hline 1. & $\begin{array}{l}\text { Keterampilan Proses Sains }\left(\mathrm{X}_{1}\right) \\
\text { dan Hasil Belajar Fisika }\left(\mathrm{X}_{4}\right)\end{array}$ & 0,519 & 5,131 & \multirow{5}{*}{1,98} & \multirow{5}{*}{$\begin{array}{l}t_{\text {hitung }}>t_{\text {tabel }} \\
\text { Koefisien } \\
\text { Korelasi } \\
\text { signifikan }\end{array}$} \\
\hline 2. & $\begin{array}{l}\text { Penalaran }\left(\mathrm{X}_{2}\right) \text { dan Hasil } \\
\text { Belajar Fisika }\left(\mathrm{X}_{4}\right)\end{array}$ & 0,498 & 4,926 & & \\
\hline 3. & $\begin{array}{l}\text { Pemecahan Masalah }\left(\mathrm{X}_{3}\right) \text { dan } \\
\text { Hasil Belajar Fisika }\left(\mathrm{X}_{4}\right)\end{array}$ & 0,526 & 5,203 & & \\
\hline 4. & $\begin{array}{l}\text { Keterampilan Proses Sains }\left(\mathrm{X}_{1}\right) \\
\text { dan Pemecahan Masalah }\left(\mathrm{X}_{3}\right)\end{array}$ & 0,515 & 5,096 & & \\
\hline 5. & $\begin{array}{l}\text { Penalaran }\left(X_{2}\right) \text { dan Pemecahan } \\
\text { Masalah }\left(X_{3}\right)\end{array}$ & 0,485 & 4,792 & & \\
\hline
\end{tabular}

Koefisien korelasi tersebut digunakan untuk menghitung koefisien jalur melalui persamaan struktural yang dirumuskan berdasarkan diagram jalur. Rangkuman hasil perhitungan koefisien jalur disajikan pada tabel berikut:

Tabel 7. Hasil Pengujian Signifikansi Koefisien Jalur

\begin{tabular}{|c|c|c|c|c|c|}
\hline No. & Variabel & $\begin{array}{l}\text { Koefisien } \\
\text { Jalur }\end{array}$ & $t_{\text {hitung }}$ & $t_{\text {tabel }(\alpha=0,05)}$ & Kesimpulan \\
\hline 1. & $\begin{array}{l}\text { Pengaruh Langsung } \\
\text { Keterampilan Proses Sains } \\
\text { terhadap Hasil Belajar Fisika }\end{array}$ & 0,250 & 2,496 & \multirow{5}{*}{1,985} & \multirow{5}{*}{$\begin{array}{l}t_{\text {hitung }}>t_{\text {tabel }} \\
\text { Koefisien } \\
\text { Jalur } \\
\text { Signifikan }\end{array}$} \\
\hline 2. & $\begin{array}{l}\text { Pengaruh Langsung Penalaran } \\
\text { terhadap Hasil Belajar Fisika }\end{array}$ & 0,225 & 2,287 & & \\
\hline 3. & $\begin{array}{l}\text { Pengaruh Langsung Pemecahan } \\
\text { Masalah terhadap Hasil Belajar } \\
\text { Fisika }\end{array}$ & 0,288 & 2,977 & & \\
\hline 4. & $\begin{array}{l}\text { Pengaruh Langsung } \\
\text { Keterampilan Proses Sains } \\
\text { terhadap Pemecahan Masalah }\end{array}$ & 0,359 & 3,641 & & \\
\hline 5. & $\begin{array}{l}\text { Pengaruh Langsung Penalaran } \\
\text { terhadap Pemecahan Masalah }\end{array}$ & 0,293 & 2,970 & & \\
\hline
\end{tabular}


Tabel 7 menunjukkan bahwa koefisien jalur setelah diuji dengan menggunakan $u j i-t$, di mana $t_{\text {hitung }}>t_{\text {tabel }(\alpha=0,05)}$, maka dapat disimpulkan bahwa koefisien jalur di atas seluruhnya signifikan, dengan demikian tidak dilakukan modifikasi model. Besar pengaruh langsung keterampilan proses sains terhadap hasil belajar fisika sebesar $0,0625(6,25 \%)$; penalaran terhadap hasil belajar fisika $0,0505(5,05 \%)$; pemecahan masalah terhadap hasil belajar fisika $0,0829(8,29 \%)$; keterampilan proses sains terhadap pemecahan masalah $0,1289(12,89 \%)$; dan pengaruh langsung penalaran terhadap pemecahan masalah yaitu $0,0858(8,58 \%)$.

Koefisien determinasi untuk pengaruh keterampilan proses sains $\left(\mathrm{X}_{1}\right)$ dan penalaran $\left(\mathrm{X}_{2}\right)$ secara bersama terhadap pemecahan masalah $\left(\mathrm{X}_{3}\right)$ yaitu $R^{2}{ }_{3.12}=0,327$, dan koefisien residu $\varepsilon_{1}=0,82$ serta diketahui pengaruh variabel lain sebesar 0,673 . Koefisien determinasi untuk variabel keterampilan proses sains $\left(\mathrm{X}_{1}\right)$, penalaran $\left(\mathrm{X}_{2}\right)$, dan pemecahan masalah $\left(\mathrm{X}_{3}\right)$ secara bersama terhadap hasil belajar fisika $\left(\mathrm{X}_{4}\right)$ adalah $R_{4.123}^{2}=0,393$, dan koefisien residu $\varepsilon_{2}=0,78$ serta pengaruh variabel lain sebesar 0,607 . Hal ini menunjukkan bahwa masih kemungkinan terdapat pengaruh variabel lain terhadap variabel hasil belajar fisika. Berikut diagram hasil analisis jalur:

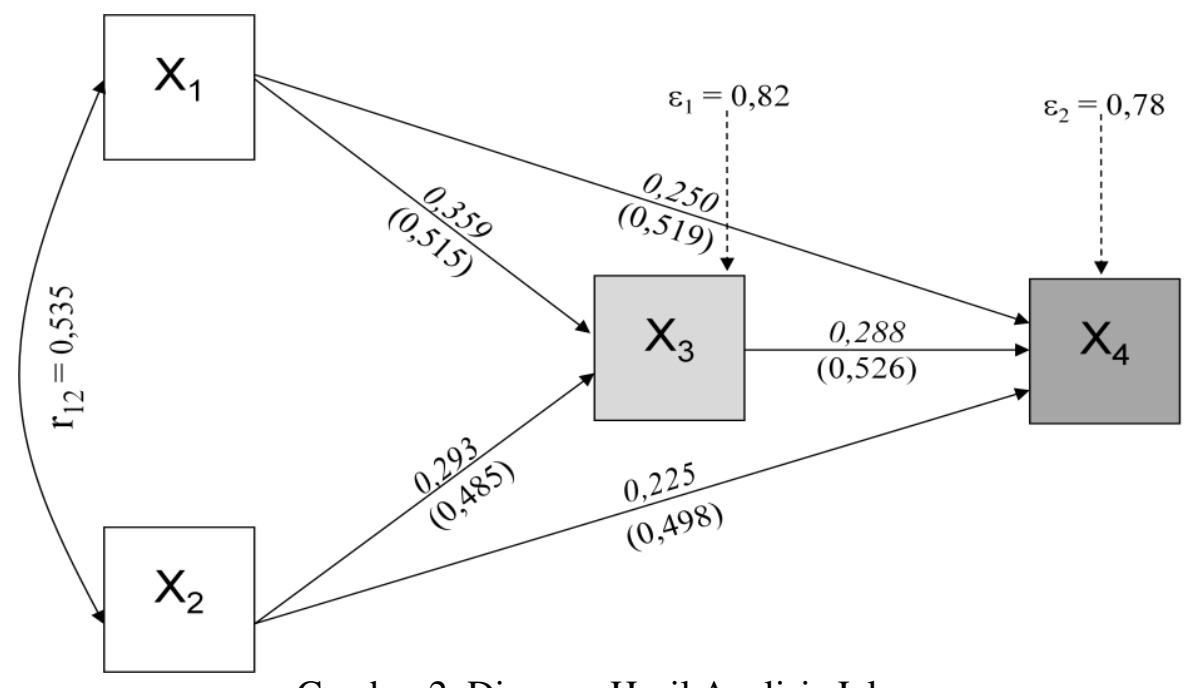

Gambar 2. Diagram Hasil Analisis Jalur

Terdapat 5 (lima) hipotesis penelitian yang akan diuji secara statistik serta pembahasan hasil penelitian secara rinci dijelaskan sebagai berikut:

\section{Pengaruh Langsung Keterampilan Proses Sains terhadap Hasil Belajar Fisika}

Rumusan hipotesis penelitian pertama menyatakan: "terdapat pengaruh langsung positif keterampilan proses sains $\left(\mathrm{X}_{1}\right)$ terhadap hasil belajar fisika $\left(\mathrm{X}_{4}\right)$ ". Hipotesis statistik $H_{o}: \beta_{41} \leq 0$ dan $H_{1}: \beta_{41}>0$, dengan syarat pengujian adalah jika $t_{\text {hitung }}>$ $t_{\text {tabel }(0,05)}$, maka $H_{o}$ ditolak, dan jika $t_{\text {hitung }}<t_{\text {tabel }(0,05)}, H_{o}$ diterima. Hasil perhitungan koefisien jalur diperoleh $p_{41}=0,250$, nilai ini lebih besar dari kriteria praktis $p_{41}=0,250>0,05$, dan diperkuat dengan hasil $u j i-t$ yang menunjukkan $t_{\text {hitung }}=2,496$, sedangkan $t_{\text {tabel }}=1,985$ dengan $d k=98$ pada tingkat ketelitian $\alpha=0,05$, sehiingga $t_{\text {hitung }}=2,496>t_{\text {tabel }(0,05 ; 98)}=1,985$, berarti koefisien jalur $p_{41}$ signifikan. Dengan demikian dapat disimpulkan $H_{o}$ ditolak dan $H_{1}$ diterima, artinya terbukti bahwa terdapat pengaruh langsung positif keterampilan proses sains terhadap 
hasil belajar fisika. Hasil belajar fisika dapat ditinmgkatkan dengan mengembangkan keterampilan proses sains.

Besar pengaruh kontribusi keterampilan proses sains terhadap hasil belajar fisika yaitu 0,0625 atau 6,25\%. Hasil tersebut dapat diterima, oleh karena hasil belajar fisika merupakan kemampuan yang dimiliki siswa setelah melalui proses pembelajaran. Proses pembelajaran merupakan upaya siswa untuk memperoleh pengetahuan tentang fisika. Beyer (1991: 9) mengungkapkan, keterampilan proses dapat digunakan sebagai alat atau piranti (tools) untuk memahami materi. Prinsip, konsep, dan teori, serta hukum fisika dapat diperoleh, diiolah, dipahami, dan dikuasi oleh siswa melalui kemampuankemampuan proses sains, seperti pengamatan (observasi), memprediksi, meramal, berhipotesis, dan eksperimen. Hasil penelitian tersebut dapat dipahami, dengan argumentasi yang logis, misalnya pendapat Cain dan Evans (1990: 4-5) menyatakan bahwa keberhasilan belajar ditentukan oleh pengembangan keterampilan proses sains. Keterampilan proses sains diperlukan, agar siswa dapat memiliki kemampuankemampuan tersebut. Oleh karena itu, pengaruh keterampilan proses sains dapat meningkatkan hasil belajar fisika. Meskipun demikian faktor lain seperti sikap ilmiah mempunyai pengaruh terhadap hasil belajar fisika.

\section{Pengaruh Langsung Penalaran terhadap Hasil Belajar Fisika}

Rumusan hipotesis penelitian kedua menyatakan: "terdapat pengaruh langsung positif penalaran $\left(\mathrm{X}_{2}\right)$ terhadap hasil belajar fisika $\left(\mathrm{X}_{4}\right)$ ". Hipotesis statistik $H_{0}: \beta_{42} \leq 0$ dan $H_{1}: \beta_{42}>0$, dengan syarat pengujian adalah jika $t_{\text {hitung }}>t_{\text {tabel }(0,05)}$, maka $H_{o}$ ditolak, dan jika $t_{\text {hitung }}<t_{\text {tabel }(0,05)}, H_{o}$ diterima. Hasil perhitungan koefisien jalur diperoleh $p_{42}=0,225$, nilai ini lebih besar dari kriteria praktis $p_{42}=0,225>0,05$, dan diperkuat dengan hasil $u j i-t$ yang menunjukkan $t_{\text {hitung }}=2,287$, sedangkan $t_{\text {tabel }}=$ 1,985 dengan $d k=98$ pada tingkat ketelitian $\alpha=0,05$, sehiingga $t_{\text {hitung }}=2,287>$ $t_{\text {tabel }(0,05 ; 98)}=1,985$, berarti koefisien jalur $p_{42}$ signifikan. Dengan demikian dapat disimpulkan $H_{o}$ ditolak dan $H_{1}$ diterima, artinya terbukti bahwa terdapat pengaruh langsung positif penalaran terhadap hasil belajar fisika. Hasil belajar fisika dapat ditingkatkan dengan meningkatkan kemampuan penalaran fisika pada siswa.

Hasil tersebut dapat diketahui kontribusi kemampuan penalaran mempunyai pengaruh sebesar 0,0506 atau 5,06\% terhadap hasil belajar fisika. Hal ini dapat dipahami bahwa kemampuan penalaran merupakan indikasi seseorang memiliki tingkat kecerdasan, yang mempengaruhi hasil belajar fisika. Hal ini diperkuat dengan pendapat logis Young (2002: 1), bahwa fisika merupakan sains yang menguraikan, menganalisis struktur dan fenomena yang akan ditemukan aturan atau hukum alam, menerangkan gejalanya berdasarkan struktur logika sebab akibat, kemudian diinterpretasikan dan dikontsruk menjadi pengetahuan, konsep, prinsip, teori, dan hukum fisika dengan menggunakan kemampuan penalaran . Kemampuan penalaran diperlukan untuk memahami konsep, prinsip, teori, dan hukum fisika yang diajarkan. Pengetahuan fisika terdiri atas banyak konsep dan prinsip yang pada umumnya sangat abstrak. Siswa dapat memahami, menguasi materi yang diajarkan oleh guru melalui sebuah penalaran. Kemampuan penalaran yang dimiliki siswa dapat menterjemahkan konsep fisika yang abstrak. Hal ini terjadi pada tahap perkembangan kognitif formal operasional, menurut Syah (2010: 72) diantaranya yaitu kemampuan menggunakan prinsip-prinsip abstrak. Kemampuan penalaran juga diperlukan untuk memecahkan permasalahan atau soal fisika, siswa yang memiliki kemampuan penalaran dapat menggunakan logika berpikir untuk menggambarkan soal fisika yang abstrak, dan kemampuan analisis dapat digunakan untuk memecahkan soal fisika, oleh karena itu siswa mampu menjawab soal fisika yang diberikan pada tes hasil belajar fisika. Dapat dikatakan bahwa, kemampuan penalaran 
berpengaruh terhadap peningkatan hasil belajar fisika. Meskipun demikian, faktor lain seperti berpikir kritis (critical thinking) mungkin juga berpengaruh terhadap hasil belajar fisika.

\section{Pengaruh Langsung Pemecahan Masalah terhadap Hasil Belajar Fisika}

Rumusan hipotesis penelitian ketiga menyatakan: "terdapat pengaruh langsung positif pemecahan masalah $\left(\mathrm{X}_{3}\right)$ terhadap hasil belajar fisika $\left(\mathrm{X}_{4}\right)$ ". Hipotesis statistik $H_{o}: \beta_{43} \leq 0$ dan $H_{1}: \beta_{43}>0$, dengan syarat pengujian adalah jika $t_{\text {hitung }}>t_{\text {tabel }(0,05)}$, maka $H_{o}$ ditolak, dan jika $t_{\text {hitung }}<t_{\text {tabel }(0,05)}, H_{o}$ diterima. Hasil perhitungan koefisien jalur diperoleh $p_{43}=0,288$, dan hasil uji $-t$ menunjukkan $t_{\text {hitung }}=2,977$, sedangkan $t_{\text {tabel }}=1,985$ dengan $d k=98$ pada tingkat ketelitian $\alpha=0,05$, sehiingga $t_{\text {hitung }}=$ $2,977>t_{\text {tabel }(0,05 ; 98)}=1,985$, berarti koefisien jalur $p_{43}$ signifikan. Dengan demikian dapat disimpulkan $H_{o}$ ditolak dan $H_{1}$ diterima, artinya terbukti bahwa terdapat pengaruh langsung positif pemecahan masalah terhadap hasil belajar fisika. Temuan ini dapat juga diinterpretasikan bahwa pemecahan masalah berpengaruh signifikan terhadap hasil belajar fisika. Dengan demikian, pengaruh kemampuan pemecahan masalah dapat meningkatkan hasil belajar fisika siswa.

Diketahui besar pengaruh pemecahan masalah terhadap hasil belajar fisika adalah 0,0829 , artinya pemecahan masalah berkontribusi mempengaruhi hasil belajar fisika sebesar 8,29\%. Hasil belajar fisika merupakan kompetensi siswa setelah mengikuti proses belajar selama kurun waktu tertentu dan telah mencapai standar kompetensi dan kompetensi dasar melalui serangakian tes hasil belajar fisika. Selain penguasaan materi, siswa juga harus memiliki kemampuan strategi pemecahan masalah, agar dapat menjawab, menyelesaikan, dan atau memecahkan soal fisika. Pemecahan masalah merupakan kemampuan siswa dalam menggunakan proses berpikirnya untuk memecahkan masalah melalui pengumpulan fakta-fakta, analisis informasi atau pengetahuan, menyusun berbagai alternative strategi pemecahan yang paling efektif. Kemampuan pemecahan masalah fisika dapat ditumbuhkan melalui latihan penyelesaian soal, baik secara kulitatif maupun kuantitatif. Dalam padangan Syah (2008: 121), pembelajaran juga dianjurkan menggunakan model dan strategi pembelajaran yang berorientasi pada cara pemecahan masalah. Pemahaman konsep, teori, prinsip atau hukum fisika melalui proses berpikir logis, berpikir abstrak, generalisasi, analitik, dan sistematis juga penting sebagai kemampuan dasar untuk memecahkan masalah fisika. Oleh karena itu dapat dikatakan bahwa kemampuan pemecahan masalah dapat meningkatkan hasil belajar fisika. Namun demikian, kemampuan pemecahan masalah juga dipengaruhi oleh faktor lain seperti pemahaman konsep fisika, dan kemampuan numerik atau operasi matematika.

\section{Pengaruh Langsung Keterampilan Proses Sains terhadap Pemecahan Masalah}

Rumusan hipotesis penelitian keempat menyatakan: "terdapat pengaruh langsung positif keterampilan proses sains $\left(\mathrm{X}_{1}\right)$ terhadap pemecahan masalah $\left(\mathrm{X}_{3}\right)$ ". Hipotesis statistik $H_{o}: \beta_{31} \leq 0$ dan $H_{1}: \beta_{31}>0$, dengan syarat pengujian adalah jika $t_{\text {hitung }}>$ $t_{\text {tabel }(0,05)}$, maka $H_{o}$ ditolak, dan jika $t_{\text {hitung }}<t_{\text {tabel }(0,05)}, H_{o}$ diterima. Hasil perhitungan koefisien jalur diperoleh $p_{31}=0,359$, dan hasil $u j i-t$ yang menunjukkan $t_{\text {hitung }}=3,641$, sedangkan $t_{\text {tabel }}=1,985$ dengan $d k=98$ pada tingkat ketelitian $\alpha=0,05$, sehiingga $t_{\text {hitung }}=3,641>t_{\text {tabel }(0,05 ; 98)}=1,985$, berarti koefisien jalur $p_{31}$ signifikan. Hasil ini diperkuat dengan $p_{31}=0,359>0,05$ (kriteria praktis), yang artinya signifikan. Dengan demikian dapat disimpulkan $H_{o}$ ditolak dan $H_{1}$ diterima, artinya terbukti bahwa terdapat pengaruh langsung positif keterampilan proses sains 
terhadap pemecahan masalah. Temuan ini dapat juga diinterpretasikan bahwa keterampilan proses sains berpengaruh signifikan terhadap pemecahan masalah.

Koefisien tersebut menunjukkan bahwa keterampilan proses sains berkonstribusi mempunyai pengaruh langsung terhadap kemampuan pemecahan masalah sebesar 0,1289 atau $12,89 \%$. Keterampilan proses sains merupakan teknik atau prosedur yang digunakan untuk mencari, memperoleh, dan mengolah ilmu pengetahuan sesuai dengan metode ilmiah. Hal ini juga diungkapkan oleh Wetzel (2010) bahwa keterampilan proses sains merupakan dasar pemecahan masalah dalam sains dan metode ilmiah. Siswa yang terbiasa dengan metode ilmiah, dapat menggunakannya untuk memecahkan masalah. Masalah dalam soal fisika yang abstrak, atau disertai dengan gambar, grafik, tabel dan sebagainya dapat dipahami oleh siswa yang memiliki keterampilan proses sains, jika siswa memahami suatu inti masalah dalam soal, maka dapat menggunakan metode ilmiah yang dimiliki untuk memecahkan masalah. Santosa (2000: 67) keterampilan proses sains perlu ditanamkan, dan dilatih, agar mampu mencari, menemukan ilmu pengetahuan, dan memecahkan masalah. Dalam pembelajaran di kelas, guru berperan dalam melatih, dan mengembangkan keterampilan proses sains, serta memberikan latihan soal yang membutuhkan kemampuan pemecahan masalah. Sehingga, dikatakan bahwa pengaruh keterampilan proses sains dapat meningkatkan kemampuan pemecahan masalah. Meskipun demikian, terdapat faktor lain, misalnya kreativitas juga mempengaruhi keterampilan proses sains.

\section{Pengaruh Langsung Penalaran terhadap Pemecahan Masalah}

Rumusan hipotesis penelitian kelima menyatakan: "terdapat pengaruh langsung positif penalaran $\left(\mathrm{X}_{2}\right)$ terhadap pemecahan massalah $\left(\mathrm{X}_{3}\right)$ ". Hipotesis statistik $H_{o}: \beta_{32} \leq$ 0 dan $H_{1}: \beta_{32}>0$, dengan syarat pengujian adalah jika $t_{\text {hitung }}>t_{\text {tabel }(0,05)}$, maka $H_{o}$ ditolak, dan jika $t_{\text {hitung }}<t_{\text {tabel }(0,05)}, H_{o}$ diterima. Hasil perhitungan koefisien jalur diperoleh $p_{32}=0,293$, dan hasil $u j i-t$ yang menunjukkan $t_{\text {hitung }}=2,970$, sedangkan $t_{\text {tabel }}=1,985$ dengan $d k=98$ pada tingkat ketelitian $\alpha=0,05$, sehingga $t_{\text {hitung }}=$ $2,970>t_{\text {tabel }(0,05 ; 98)}=1,985$, berarti koefisien jalur $p_{32}$ signifikan. Hasil ini diperkuat dengan $p_{32}=0,293>0,05$ (kriteria praktis), yang artinya signifikan. Dengan demikian dapat disimpulkan $H_{o}$ ditolak dan $H_{1}$ diterima, artinya terbukti bahwa terdapat pengaruh langsung positif penalaran terhadap pemecahan masalah. Hasil penelitian dapat diinterpretasikan bahwa penalaran berpengaruh signifikan terhadap kemampuan pemecahan masalah. Pengaruh kemampuan penalaran dapat mengakibatkan peningkatkan kemampuan pemecahan masalah.

Dengan hasil tersebut, penalaran berpengaruh serta berkonstribusi efektif sebesar 0,0858 atau $8,58 \%$ terhadap pemecahan masalah. Dalam memecahkan soal fisika, maka agar dapat menjawab, atau memcahkan masalah dalam soal, siswa harus menggunakan logika berpikirnya, dan menganalisis masalah sehingga siswa mamapu menjawab soal atau memecahkan masalah dalam soal. Hal ini diperkuat dengan pendapat Hamalik (2010: 151) yang menyatakan bahwa pemecahan masalah menuntut kemampuan tertentu pada individu yang hendak memecahkan masalah. Kemampuan yang diperlukan misalnya kemampuan berpikir, penalaran dan juga kemampuan kognitif, memerlukan kemampuan dalam mengamati, bertanya, berkomunikasi dan berinteraksi dangan lingkungan, agar pemikiran terarah pada hal-hal yang bertalian dengan upaya memecahkan masalah. Teori perkembangan kognitif dalam Yusuf (2001: 6), tahap operasi formal, merupakan operasi mental tingkat tinggi, berhubungan dengan berpikir abstrak dan berhipotesis, memecahkan masalah melalui pengujian semua aternatif. Kemampuan memecahkan masalah harus ditunjang oleh kemampuan panalaran, yaitu kemampuan melihat hubungan sebab akibat. Siswa dapat menjawab soal fisika, maka diperlukan kemampuan penalaran. 
Oleh karena itu, pengaruh penalaran dapat meningkatkan kemampuan pemecahan masalah. Meskipun demikian, terdapat faktor lain seperti strategi kognitif, gaya kognitif, perkembangan kognitif dan beberapa aspek psikologis juga mempengaruhi kemampuan pemecahan masalah.

\section{PENUTUP}

\section{Kesimpulan}

Berdasarkan pembahasan hasil penelitian, diperoleh beberapa kesimpulan yang terkait dengan rumusan masalah yang ingin dijawab dari hipotesis penelitian, yaitu sebagai berikut: (1) Keterampian proses sains, penalaran, dan pemecahan masalah berpengaruh positif yang mengakibatkan peningkatan hasil belajar fisika. Kesimpulan penelitian tersebut memberikan implikasi bahwa hasil belajar fisika dapat ditingkatkan dengan melatih keterampilan proses sains, daya nalar, dan strategi pemecahan masalah fisika. (2) Keterampilan proses sains, dan penalaran berpengaruh positif yang mengakibatkan peningkatan kemampuan pemecahan masalah. Kesimpulan penelitian memberikan implikasi bahwa kemampuan pemecahan masalah dapat ditingkatkan dengan melatih dan mengembangkan keterampilan proses sains, kemampuan berpikir logis dan analitis. Implikasi penelitian secara umum adalah bahwa untuk meningkatkan kualitas hasil belajar fisika, penggunaan suatu metode, pendekatan pembelajaran yang tepat dengan memperhatikan perkembangan kognitif siswa.

\section{Saran}

Setelah memperhatikan hasil penelitian, kesimpulan dan implikasinya, maka peneliti memberikan beberapa saran, diantaranya: pemberdayaan laboratorium, proses pembelajaran fisika sebaiknya tidak hanya mencakup aspek pemahaman, melainkan juga aspek keterampilan berpikir dan aspek sikap. Dalam pemilihan metode, pendektan, pembelajaran, hendaknya guru memperhatikan perkembangan kognitif siswa. Penelitian ini memungkinkan dapat dilakukan penelitian lanjutan, hendaknya memperhatikan keterbatasan penelitian diantaranya adalah: (1) variabel penelitian lain yang diduga berpengaruh terhadap hasil belajar fisika, (2) pemilihan tempat penelitian atau sekolah dengan karakteristik yang sama untuk meminimalisir subjektivitas, (3) menambah jumlah sampel penelitian agar lebih memperkuat dalam generalisasi hasil penelitian, dan (4) penyempurnaan instrumen penelitian, agar hasil penelitian valid dan reliabel.

\section{DAFTAR PUSTAKA}

Abruscato, Joseph.1992. Teaching Children Science: A Discovery Approach. Boston: Allyn dan Bacon.

Anderson, John R. 1985. Cognitive Psychology and It's Implications. New York: W.H. Freeman and Company.

Barbey, A K dan L W. Barsalou. 2009. Reasoning and Problem Solving: Models. http://www.psychology.emory.edu. 19 April 2011.

Beyer, Barry K. 1991. Teaching Thinking Skills: A Hand Book for Elementary School Teacher. New York: Allyn and Bacon.

Bloom, Benjamin S, Max D. Engelhart, Edwart J. Forst, Walker H. Hill, dan David R. Krathwohl. 1978. Taxonomy of Educational Objective: The Classification of Educational Goals, Handbook 1: Cognitive Domain. New York: David McKay Company.

Cain, Sandra E dan Jack M. Evans. 1990. Sciencing: An Involvement Approach to Elementary Science Methods. Columbus: Merril Publishing Company. 
Charlesworth, Rosalind dan Karen K. Lind. 1995. Math and Science for Young Children. Washington: Delmar Publisher.

Efendi, Ridwan. 2010. Kemampuan Fisika Siswa Indonesia dalam TIMSS (Trend Of International On Mathematics and Science Study)." Proseding Seminar Nasional Fisika 2010 Jurusan Pendidikan Fisika FPMIPA, Universitas Pendidikan Indonesia. http://www.fi.itb.ac.id. 24 April 2011.

Gagne, Robert M. 1983. The Condition of Learning. New York: Holt, Rinehart dan Witson, Inc.

Gega, Pete C. 1987. Science Elementary Education. New York: John Willey dan Son.

Giambattista, Alan, Betty McCarthy Richardson, dan Robert C. Richardson. 2010.

Physics. New York: McGraw-Hill.

Gronlund, N. E. dan Robert L. Linn. 1990. Measurement and Evaluation Teaching. New York: MacMillan Publishing Company.

Hamalik, Oemar. 2010. Kurikulum dan Pembelajaran. Jakarta: PT. Bumi Aksara.

Hergenhahn, B. R dan Mathew H. Olson. 2008. Teori Belajar, terjemahan Tri Wibowo B. S. Jakarta: Prenada Media Group.

Hopkins, Charles D dan Richard L. Antes. 1990. Classroom Measurement and Evaluation. Illinois: Peacock Publishers.

Nasution, S. 2010. Didaktik Asas-Asas Mengajar. Jakarta: PT. Bumi Aksara.

Nitko, Anthony J. 2001. Educational Assessment of Students. New Jersey: Prentice Hall., Inc.

Rapar, Jan Hendrik. 1996. Pengantar Logika: Asas-asas Penalaran Sistematis. Yogyakarta: Kanisius.

Reif, Frederick. 1995. Millikan Lecture 1994: Understanding and Teaching Important Scientific Thought Proceses. American Journal of Physics. Vol. 63 (1), Januari 1995. https://www.cmu.edu/teaching/resources/Research/ cognitive/Reif1995.pdf. 29 April 2011.

Rosser, Rosemary A dan Glen I. Nigholson. 1984. Educational Psychology Principle in Practice. Boston: Litle, Brown and Company.

Santrock, John W. 2008. Psikologi Pendidikan, terjemahan Tri Wibowo B. S. Jakarta: Kencana Prenada Media Group.

Sardiman, A. M. 1996. Interaksi dan Motivasi Belajar Mengajar. Jakarta: Raja Grafindo Persada.

Small, Melinda Y. 1996. Cognitive Development. New York: Harcourt Brace Jovanovich.

Sudjana, Nana dan Ibrahim. 1989. Penelitian dan Penilaian Pendidikan. Bandung: Sinar Baru.

Sudjana. 2001. Teknik Analisis Regresi dan Korelasi. Bandung: Tarsito.

Sugiyono. 2009. Statistika untuk Penelitian. Bandung: Alfabeta.

Suriasumantri, Jujun S. 1998. Filsafat iImu: Sebuah Pengantar Populer. Jakarta: Pustaka Sinar Harapan.

Syah, Muhibbin. 2010. Psikologi Pendidikan dengan Pendekatan Baru. Bandung: PT. Remaja Rosdakarya.

Syarif, Supardi, Darwan Syah, dan Eneng Muslihah. 2010. Strategi Belajar Mengajar. Jakarta: Diadit Media.

Tim Pustaka Yustisia. 2007. Panduan Lengkap KTSP. Jakarta: Pustaka Yustisia.

Tjalla, Awaludin. Potret Mutu Pendidikan Indonesia Ditinjau dari Hasil-Hasil Studi Internasional. http://pustaka.ut.ac.id/pdfartikel/TIG601.pdf. 26 April 2011. 
Wetzel, David R. 2008. Problem Solving and Science Process Skills. http://teachertipstraining.suite101.com/article.cfm/problem solving and science process skills. 7 April 2010.

Whelan, Patrick Michael dan M. J. Hodgson. 1987. Esential Principles of Physics. London: Clay Ltd.

Whyne, Harlen. 1985. Teaching Learning Primary Science. London: Harper dan Row Ltd.

Wolfinger, Donald M. 1994. Science and Mathematics in Early Childhood. New York: Harper Collins College Publishers.

World Bank. 2005. Perbandingan Akses dan Kualitas tentang Prestasi Pendidikan di Beberapa Negara. http://siteresources.worldbank.org. 24 April 2011.

Young, Hugh D, Roger A. Freedman, T. R Sandin, dan A. Lewis Ford. 2002. Sears dan Zemansky Fisika Universitas Jilid 1, terjemahan Endang Juliastuti. Jakarta: Erlangga.

Yusuf L. N, Syamsu. 2001. Psikologi Perkembangan Anak dan Remaja. Bandung: PT. Remaja Rosdakarya. 